УДК 355.04(477)

Ольга Федорівна Сальнікова (доктор держ. управління, с.н.с.)

Віктор Сисойович Корендович (канд. техн. наук, доцент)

Павло Андрійович Мінеєв

Сергій Ігорович Антоненко

Національний університет оборони Украӥни імені Івана Черняховського, Київ, Украӥна

\title{
АНАЛІЗ ВОЄННИХ АСПЕКТІВ ГІБРИДНОЇ ВІЙНИ: ÏХ ЗМІСТ ТА УРОКИ ПРОТИДії
}

\begin{abstract}
Воєнні дї Російської Федерації з початку лютого 2014 року в Україні актуалізували парадигму збройного конфлікту, коли сторона, щзо вчиняє агресію, себе не афішує. Така модель, щзо поєднує різні засоби ведення воєнних дій із застосуванням звичайних видів озброєння, нерегулярних військ $і$ формувань, вчинення терористичних актів $і$ застосування сепаратистських рухів відома у світі з початку XXI cm. як гібридна війна. Саме зміна парадигми сучасного збройного конфлікту та гібридна агресія РФ проти України прискорили трансформачї $і$ структурні зрушення у секторі безпеки та оборони України. Розвиток і повноцінне функціонування сектору безпеки та оборони Украӥни, який би відповідав умовам сучасного воєнного конфлікту, практично неможливі без наукового аналізу воєнних аспектів гібридної війни та об'єктивного діагностування проблем діяльності існуючої системи воєнної безпеки в умовах операції об'єднаних сил. У статті проаналізовано воєнні аспекти гібридної війни та запропоновано пріоритетні напрями протидії російській гібридній війні, а також майбутнім гібридним загрозам.

Ключові слова: гібридна війна; оборона держави; застосування збройних сил; сили оборони; система управління збройними силами; об'єднане керівництво силами оборони.
\end{abstract}

\section{Вступ}

Збройну агресію Росії проти України ми пов'язуємо з особливою формою їі ведення, яка на початку XXI століття стала відомою як “гібридна війна". Фахівці сходяться на думці, що ця особлива форма війни не $є$ новою. Так, зокрема, системно привернув увагу до проблеми гібридної війни американський науковець Френк Хоффман $[1,2]$, зазначивши у квітні 2009 року: “...Деякі аналітики припускають, що майбутні конфлікти будуть мультимодальними та багатоваріантними, не вписуючись в рамки простої характеристики (чорне - біле) однієї з форм ведення війни. Ці аналітики закликають приділяти більшу увагу змішаним формам війни, частота яких зростає. Така концепція найчастіше характеризується як гібридна війна. Ця теорія грунтується на інших уявленнях про конфлікт, які заслуговують на увагу".

Постановка проблеми. Досвід протидії сучасній російській збройній агресії підтверджується принциповим визначенням Клаузевіца щодо війни [3], зокрема й гібридної, як продовження політики однієї держави щодо підпорядкування іншої 3 використанням політичних, економічних, інформаційних, соціальних засобів, підтримуваних бойовими діями збройних сил, нерегулярних військових формувань та кримінальних елементів, диверсіями та саботажем. Застосування збройної сили є обов'язковим компонентом, інакше гібридна війна не $є$ війною, тільки застосування збройної сили приносить страх, смерть, фізичну розруху, чим значно підсилюе дії інших компонентів. Особливістю застосування збройної сили в гібридній війні $\epsilon$ те, що агресор всіляко це заперечує, маскуючи свої бойові дії та прагнучи показати їх як громадянську війну у країні-жертві. У цій війні ніхто зі сторони агресора не хоче стати героєм. Якщо початок “класичних” війн легко простежується в історії, то визначити дату початку гібридної війни складно, їі ніколи не оголошують. Також складно визначити час закінчення війни. Дату початку гібридної війни РФ проти України можна пов'язати 3 конфліктом у районі острова Тузла чи однією з перших газових “війн”, де чітко простежуються економічні засоби тиску, які тільки у 2014 році стало можливим поєднати 3 терміном “гібридна війна". Саме газові війни та потужні пропагандистські компанії, що сіяли страх серед центральноєвропейських країн, які зіштовхнулися 3 проблемою нестачі газу всередині зими, є прикладом того, що країна-жертва може і не знати, що агресор вже почав і веде проти неї гібридну війну, до якої згодом буде додано і збройний компонент.

3 огляду на зазначене створення і повноцінне функціонування сектору безпеки та оборони України, який би відповідав умовам сучасного воєнного конфлікту практично неможливі без наукового аналізу воєнних аспектів гібридної війни та об'єктивного діагностування проблем діяльності сучасної системи воєнної безпеки в умовах операції об'єднаних сил.

Актуальність теми зумовлена тим, що модель сектору безпеки та оборони має відповідати 
умовам новітнього конфлікту, насамперед 3 ознаками гібридної війни, а тіi реформування сприяти зміцненню спроможностей, підвищенню готовності до виконання завдань за призначенням та участі у проведенні спільних бойових дій (операцій) 3 підрозділами НАТО [4-7]. Для відсічі та стримування агресора Україні разом 3 іiі міжнародними партнерами необхідно мати чітке розуміння природи й характеру гібридного конфлікту. Без глибокого філософського та наукового аналізу воєнних аспектів феномену гібридної війни створити і реалізувати ефективну систему міжнародної та національної безпеки практично неможливо, а спроби емпіричного розв'язання сучасних проблем сектору безпеки та оборони, більшість з яких за змістом і масштабами не мають аналогів в історії, не дають бажаних результатів, а іноді навіть посилюють негативні наслідки.

Аналіз останніх досліджень і публікацій. Проблеми забезпечення обороноздатності, воєнної організації держави, сектору безпеки і оборони, основні тенденції розвитку та ймовірні форми збройних конфліктів майбутнього, у тому числі гібридних, розглядали вітчизняні та зарубіжні науковці О. Василенко, В. Горбулін, О. ДузьКрятченко, О. Ільшов, В. Ліпкан, Е. Лютвак, I. Попов, В. Телелим, М. Требін, В. Чорний, Г. Яворська. Від початку XXI ст. концептуально обгрунтовували поняття гібридної війни насамперед американські воєнні теоретики Р. Глен, Дж. Гордон, Д. Кілкаллен, Дж. Маккуен, Дж. Маттіс, Дж. Мацумура, У. Немет, Е. Сімпсон, Р. Уїлкі, Н. Фрейєр, Ф. Гоффман, норвезький фахівець Г. Карлсен, нідерландський - Ф. ван Каппен та ін.

У колективній монографії, підготовленій фахівцями Національного інституту стратегічних досліджень за загальною редакцією В. Горбуліна [8], детально досліджено феномен гібридної війни, іiї сутність у контексті системної кризи світової безпеки та парадигму як новітнього виду глобального протистояння.

Разом із тим питання воєнних аспектів гібридної війни у працях науковців опрацьовано недостатньо. Очевидно, що сучасна гібридна загроза українській державності 3 боку РФ потребує пошуку нових, актуальних та адекватних відповідей на щоденні виклики. На часі розроблення системної відповіді, стратегії на довгострокову перспективу.

Перебіг сучасних воєн свідчить про необхідність розгляду та врахування не лише філософських, політичних, інформаційних, соціокультурних, техніко-економічних та геополітичних, а й воєнних складових парадигми сучасного гібридного воєнного конфлікту.

Водночас реформування системи воєнної безпеки потребує додаткових досліджень воєнних аспектів гібридної війни у теорії військового управління.
Зміна парадигми сучасного збройного конфлікту та гібридна агресія РФ проти України прискорили трансформації і структурні зрушення у секторі безпеки та оборони України. Розвиток i повноцінне функціонування сектору безпеки та оборони України, який би відповідав умовам сучасного воєнного конфлікту, практично неможливо без наукового аналізу воєнних аспектів гібридної війни та об'єктивного діагностування проблем діяльності існуючої системи воєнної безпеки в умовах операції об'єднаних сил.

Метою цієї статті $\epsilon$ аналіз воєнних аспектів гібридної війни та обгрунтування пріоритетних напрямів протидії російській гібридній війні i майбутнім гібридним загрозам.

\section{Виклад основного матеріалу дослідження}

Головними ознаками гібридної війни вважаються: агресія без офіційного оголошення війни, приховування країною-агресором своєї участі в конфлікті, широке використання нерегулярних збройних формувань (у т.ч. під прикриттям мирного населення), нехтування агресором міжнародними нормами ведення бойових дій та чинними угодами і досягнутими домовленостями, взаємні заходи політичного та економічного тиску (за формального збереження зв'язків між двома країнами), широка пропаганда та контрпропаганда із застосуванням “брудних" інформаційних технологій, протистояння $\mathrm{y}$ кібернетичному просторі тощо.

Для розуміння проблеми визначимо які ж аспекти гібридної війни можна вважати саме воєнними. Звернемо увагу на висловлювання начальника генерального штабу країни-агресора В. Герасимова у статті "Ценность науки в предвидении” [9]: “... И сами “правила войны” существенно изменились. Возросла роль невоенных способов в достижении политических и стратегических целей, которые в ряде случаев по своей эффективности значительно превзошли силу оружия...". Там же наведено доцільне співвідношення воєнних та невоєнних заходів 1:4. При цьому до воєнних заходів віднесено: інформаційне протиборство, стратегічне стримування, ведення бойових дій та ведення міжнародних операцій, що є класичними формами ведення війни, але в контексті гібридної війни важливе їх співвідношення 3 невоєнними методами.

Розглянемо воєнні аспекти гібридної війни в контексті їх реалізації РФ проти України з огляду на такі положення: гібридна війна не може існувати без військової компоненти; форми та способи застосування збройної сили посилюють всі невоєнні складові гібридної війни (політичну, економічну, інформаційну, соціальну тощо), але при цьому не перевищують порогового рівня, який відповідає відкритій агресії; застосування військової сили посилюється невоєнними формами протиборства. Зважаючи на це воєнними 
аспектами гібридної війни будемо вважати:

інформаційне протиборство або інформаційну

війну, що безпосередньо посилюють ефект від бойових дій;

ведення бойових дій сторонами конфлікту;

стримування агресії (стосується країни-жертви гібридної війни).

Зупинимося на кожному з цих аспектів.

Інформаційне протиборство, спрямоване на дезінформацію і на перший погляд його складно вважати воєнним аспектом, але насправді неможливо відокремити від воєнних дій, адже його результат часто перевершує воєнний ефект. Дезінформація є способом психологічного впливу, що полягає в намірі надати об'єкту таку інформацію, яка введе його в оману стосовно справжнього стану справ та створить спотворену реальність. Інформаційне протиборство полягає в поширенні перекручених, неповних або свідомо неправдивих відомостей для досягнення пропагандистських, воєнних (введення противника в оману), комерційних або інших цілей [10].

У цьому контексті доцільно згадати Резолюцію Європарламенту від 15 січня 2015 року щодо України, пунктом 5 якої визначено, що Європарламент рішуче засуджує агресивну i експансіоністську політику Росії та розв'язану і неоголошену гібридну війну проти України, яка практично включає інформаційну війну 3 елементами кібервійни, використання регулярних і нерегулярних сил, пропаганду, енергетичний шантаж, економічний тиск, дипломатичну та політичну дестабілізацію [11] .

Російська Федерація розпочала інформаційне протиборство ще задовго до анексії Криму, нарощуючи його паралельно 3 підвищенням рівня протистояння в ході Революції гідності, формуванням неприйняття іiі ідей та цінностей значними верствами населення, особливо в Криму та на Сході України. Саме інформаційна складова (дезінформація та пропаганда) сприяла захопленню та анексії Криму, а потім створенню осередків сепаратизму на Донбасі, застосуванню “живих щитів” проти розгортання українських військ в АТО. Без інформаційного впливу для досягнення такого результату агресор мав би докласти набагато більших зусиль. Наведемо інші цілі та результати дезінформації та пропаганди в гібридній війні проти України:

створення хаосу та страху, вчинення провокацій;

дискредитація влади України та іiі здатності захистити державу i народ, маніпуляції історичною пам'яттю;

дискредитація Збройних Сил України (національна армія не $є$ кращою за противника стосовно дотримання прав людини, режиму припинення вогню, особистої поведінки, тому не слід надавати допомогу власним 3С)

дискредитація ідеї європейської євроатлантичної інтеграції, західних демократичних цінностей (твердження, що НАТО не здатне забезпечити безпеку країн-партнерів, є агресором і загрожує РФ; санкції впливають на країни Заходу, а не на РФ; всі брешуть, тому неможна покладатися на свої 3MI; всі західні уряди є маріонетками США);

виправдовування агресора (Росія не є агресором, а іiі реакція $\epsilon$ природньою через необхідність забезпечувати безпеку у своїх сферах впливу будь-якими засобами);

поширення ідеї глобальної залежності країн пострадянського простору та сусідів від російських енергоносіїв.

Ведення бойових дій агресором у гібридній війні має свої особливості. Щоб уникнути перевищення порогу прихованості збройної агресії, Росія прагнула використати слабкі сторони сил оборони України. Це природно для будь-якої війни, але слід зауважити, що агресор цю можливість використав повною мірою. Серед слабких елементів, які забезпечили перевагу агресору особливо в початковому періоді війни, ми виокремо лише шість, наведених нижче.

По-перше. Російське керівництво враховувало недостатню ефективність системи державного управління суб'єктами забезпечення національної безпеки України у воєнній сфері та відсутність на час розв'язання агресії об'єднаного керівництва силами оборони. Наявність цих чинників забезпечила не оголошення правового режиму воєнного стану, обмежила повноваження військового командування в зоні бойових дій, позбавила українських військових можливості залучати місцеве населення та ресурси місцевих підприємств для організації оборонних робіт, а також проведення мобілізації, чим скористалися сепаратисти й російські військові підрозділи. Стратегічні комунікації та інфраструктура виявилися незахищеними, без надійної охорони та оборони, що значно активізувало диверсійні дії противника на залізничному транспорті, шляхопроводах та інших вузлах стратегічних транспортних комунікацій. Сепаратистсько налаштовані представники місцевого населення за підтримки спецслужб РФ безкарно вчиняти протиправні дії (блокували пересування військових колон, не давали змоги військам проводити навантаження та розвантаження на визначених станціях, вчиняли провокації проти військовослужбовців, погрожували проукраїнське налаштованим громадянам).

Агресор скористався також нашим зволіканням зі створення Ставки Верховного Головнокомандувача, яка мала забезпечувати стратегічне керівництво Збройними Силами України, іншими військовими формуваннями та правоохоронними органами в особливий період. Генеральний штаб Збройних Сил України у такому разі мав стати робочим органом Ставки ВГК і на законних підставах організовувати 
збирання, систематизацію та аналіз розвідданих, наявних у розпорядженні різних відомств, планувати операції, визначати оперативні завдання усім складовим силам оборони, координувати ї зусилля, готувати проекти оперативних директив та наказів Ставки ВГК тощо.

По-друге. Надання воєнному конфлікту статусу антитерористичної операції призвело до покладання керівництва на Антитерористичний центр при Службі безпеки України, який згідно зі статтею 5 Закону "Про боротьбу 3 тероризмом" відповідає за “організацію та проведення антитерористичних заходів, координацію діяльності суб'єктів боротьби 3 тероризмом відповідно до визначеної законодавством України компетенції”. Зазначене посприяло агресору в позиціонуванні себе як “сторони, що не бере участі в конфлікті".

За цих умов військове командування виявилося підпорядкованим Антитерористичному центру, а не навпаки, як це передбачено воєнним станом. Із початком антитерористичної операції 13 квітня 2014 року військові формування під керівництвом штабу Антитерористичного центру діяли відповідно до завдань і традицій такого виду операцій. Основними їх завданнями були звільнення захоплених російськими диверсантами будівель та арешт диверсійних груп.

Природно, що в умовах фактичного ведення воєнних дій посадові особи АТЦ при СБУ відповідно до специфіки фахової підготовки мали ускладнення об' єктивно оцінювати обстановку, що складалася внаслідок активного застосування збройних формувань, приймати доцільні рішення, ставити обгрунтовані завдання військам та грамотно управляти ними.

Серед проблеми, що виникли через запровадження антитерористичної операції, а не збройної відсічі агресії Росії, слід виокремити відсутність можливості судити за законами воєнного часу російських військовослужбовців, сепаратистів, найманців, оскільки вони $\epsilon$ терористами, а не комбатантами, які потрапили у полон. Оскільки не визначений стан війни між державами, на українських військових, які потрапляють у полон чи до російських військ, теж не поширюється статус військовополонених, а отже, й Женевські та Гаазькі конвенції про захист їхніх прав і правила поводження з ними.

По-третє. Агресор покладався на пасивність військових формувань України щодо блокування комунікацій Донбасу та прикриття державного кордону, вилучення зброї у місцевого населення. Важливо зазначити, що рішення про проведення у рамках АТО воєнної операції 3 відновлення контролю над кордоном i створення 10-кілометрової буферної зони були прийнято із запізненням. Власне, це мало б бути першочерговим завданням із прикриття державного кордону на самому початку російської воєнної агресії, а не через чотири місяці потому, коли було втрачено контроль над прикордонними районами.

По-четверте. Агресор передбачав, що українська сторона не візьме до уваги підступність його дій, а саме можливість збройного вторгнення російських військ на територію України, а також можливість завдавання вогневих ударів збройними силами Росії по українських силах зі своєї території. Певний час українська сторона недооцінювала противника, вважаючи, що веде боротьбу з “терористами”, а не підготовленими та добре оснащеними бойовими підрозділами, i серйозного спротиву противника не очікувала. Вipa агресора у безкарність і вседозволеність $€$ характерною ознакою цієї війни. Знищення малазійського лайнера рейсу $\mathrm{MH}-17$ є тому підтвердженням.

Так, внаслідок недооцінювання обстановки під час визначення співвідношення сил у прикордонній смузі (вузькому коридорі уздовж кордону з Росією, де 3 правого флангу - російські війська, а 3 лівого - проросійські бойовики) та відсутності достовірних розвідувальних даних Сили швидкого реагування у складі підрозділів чотирьох механізованих бригад опинилися під артилерійським вогнем російських військ із російської території та зазнали значних втрат.

Особливо слід зазначити, що українські війська не вели вогонь у відповідь по російських агресорах. Це ще один воєнний аспект гібридної війни: війська держави, яка офіційно не перебуває у стані війни, не лише вчиняють збройне вторгнення, а й ведуть артилерійський вогонь зі своєї території по військах нібито дружньої держави.

Гібридний характер конфлікту обумовлював тактику застосування сил противника. Російські війська використовувались, як правило, у другому ешелоні або резерві, прикривали тили і фланги, здійснювали вогневу підтримку силами самохідної та реактивної артилерії, в тому числі великокаліберними системами, забезпечували радіоелектронну й артилерійську розвідку. Підрозділи, які складаються 3 найманців, використовувалися переважно як передові загони для розвідки боєм українських позицій та перевірки боєздатності українських військ, несли службу на блокпостх. Саме вони зазнавали основних втрат, а їх бійці попадали в полон.

По-n'яте. Агресор створив потужну сепаратистську мережу в Україні, особливо в Криму та на сході країни, що активно забезпечувала початковий період збройної агресії, а також продовжує діяти як базовий ключовий елемент підтримання соціального напруження в суспільстві, провокацій, часто - i політичного протистояння.

По-шосте. Агресор передбачав використовувати політичні та дипломатичні механізми для формального відмежовування від конфлікту (він нібито не $є$ його учасником - це 
громадянська війна), визначив для себе статус миротворця, а також прагнув заморозити конфлікт у своїх інтересах, запропонувавши використовувати миротворчий контингент на окупованих територіях "з метою охорони миротворців ОБСЕ”.

Після підписання Мінських домовленостей війська противника, на відміну від українських підрозділів, вели систематичні бойові дії попри їх заборону. Перемир'я, запроваджене цими угодами, противник активно використовував для підвищення рівня бойової підготовки ударних підрозділів найманців, поповнення їх кваліфікованим особовим складом, здійснював маневри 3 бойовим злагодженням, поповнював i ремонтував бойову техніку. Приклад цьому операція російських окупаційних військ в січні лютому 2015 року в районі ДЕБАЛЬЦЕВО.

Російська Федерація активно використовує свій статус члена Ради Безпеки ООН, що має право вето для практичного блокування рішень щодо України.

Водночас Україна довела здатність відстоювати свій суверенітет та територіальну цілісність держави, а іiі 3С - спроможність вести бойові дії в умовах гібридної війни.

Найвагомішим результатом є те, що Україна вистояла проти сильнішого ворога і не дала йому можливості реалізувати проект “Новоросія".

В Україні попри всі складнощі проведено мобілізацію, значно покращено логістичне забезпечення військ та їх підготовку. 3 урахуванням набутого досвіду було змінено характер АТО. Головними завданнями стали, 3 одного боку, недопущення широкомасштабного вторгнення російських військ, що потребувало зміцнення й перекриття кордону підрозділами 3С України, а 3 іншого - мінімізація ескалації бойових дій 3 метою локалізації втягнення в бойові дії цивільного населення та мінімізації жертв серед нього.

Збройні Сили України, крім інших завдань визначених на початку АТО, що полягали в охороні та обороні військових об'єктів тощо, виконували завдання з вогневого придушення груп збройного опору російських диверсантів i сепаратистів, вогневої підтримки бойових дій спецпідрозділів, забезпечення розвідувальною інформацією та зв'язком сил АТО, знищення блокпостів противника та диверсійнорозвідувальних груп, повітряної підтримки й перекидання аеромобільних груп у зоні бойових дій.

У відповідь на дії диверсантів, “зелених чоловічків” та бандформувань було прийнято рішення про створення корпусу спецпідрозділів MBC загальною чисельністю 12 тис. осіб на основі цивільних формувань по всій території держави.

Службу безпеки України залучено до ширших антидиверсійних дій із виявлення російських диверсантів, запобігання диверсіям та нейтралізації шпигунської мережі російських спецслужб не лише в зоні АТО, а й по всій країні.

Для підсилення дій силових структур у рамках ATO, у тому числі з місцевого населення було створено лояльні до України добровольчі загони самооборони (зокрема батальйони “Донбас", “Азов”, “Дніпро”). Їх дії з блокування пересування бойовиків, проведення рейдів у зайнятих сепаратистами районах, охорони місцевих органів влади, не захоплених сепаратистами, виявилися досить ефективними.

Частини і підрозділи Національної гвардії України через опосередковані бойові дії 3 незаконними збройними формуваннями, відсутність чіткої лінії фронту і тилу почали вести бойові дії за принципом “всюди фронт”.

Внаслідок вжитих заходів вдалося не лише стабілізувати обстановку в тилу, а й розпочати поступове звільнення від бойовиків території Донецької та Луганської областей.

Так, у період з травня до серпень 2014 року штаб АТО спланував та провів низку операцій зі звільненню з-під контролю терористів більше 100 населених пунктів регіону, серед них МАРІУПОЛЬ, СЛОВ'ЯНСЬК, КРАМАТОРСЬК, ЩАСТЯ, СІВЕРСЬК, РУБІЖНЕ, ДЗЕРЖИНСЬК, ЛИСИЧАНСЬК.

У цей період дії сил АТО на тактичному рівні були переважно наступальними. При цьому традиційні для наступу заходи (масована вогнева підготовка та підтримка атаки, розгортання військ у батальйонні, ротні, взводні колони для переходу в атаку, прорив, що полягає у зламі оборони противника на обраних напрямках, оволодіння опорними пунктами, першою позицією), застосовували рідше, ніж вибіркове високоточне ураження критичних об'єктів противника, рішучий обхід противника 3 флангів та його оточення, широке застосування маневру військами, вогнем та запасами, рейдові, десантноштурмові, пошуково-ударні дії, дії повітряних десантів та їх поєднання.

Так, під час прикриття державного кордону на загрозливих ділянках у районі ЧЕРВОНОПАРТИЗАНСЬК - ІЗВАРИНЕ у червні 2014 року основним способом дій військ були глибокі (від 10 до 170 км) рейдові дії. Також під час цієї операції було відведено свої війська, виведено їх з-під удару противника.

У ході операції зі звільнення ЯМПОЛЯ та ЗАКОТНОГО основними способами застосування були пошукові та штурмові дії.

Під час забезпечення захоплення Луганського аеродрому 80 оаембр провела рейд близько 80 км та штурмовими діями оволоділа ним.

Результатом реалізації завдань операції в період 3 травня до серпня 2014 року стало звуження периметру району конфлікту майже на 530 км (з 950 до 420 км).

В оборонних боях застосовувалися мобільні дії військ, які означали не тільки швидке пересування 
військ до початку та у ході бойових дій, а й своєчасний маневр вогнем, вихід з-під ударів противника, високоточний вогонь по його критичних об'єктах. У боях за ПІСКИ та Донецький аеропорт 93 омбр незважаючи на значне перевищення нормативних показників (смуга оборони шириною 30 км і глибиною 45 км) застосувала спосіб маневреної оборони діяла вдало й утримала визначений рубіж.

Стримування агресора в гібридній війні $€$ особливо важливим її воєнним аспектом як у ході активної фази війни для унеможливлення переходу гібридної війни у відкриту агресію, так і після припинення бойових дій. Стримування передбачає проведення комплексу політичних, дипломатичних, економічних, інформаційних заходів всіма складовими сектору безпеки та оборони. В рамках статті наведено тільки ті заходи стримування, які стосуються воєнних аспектів гібридної війни:

створення ефективної системи управління суб'єктами забезпечення національної безпеки України у воєнній сфері, визначення чіткої вертикалі підпорядкованості та відповідальності, починаючи від Верховного головнокомандувача 3С України до командира відділення (бойової машини). Система управління має базуватися на реалістичному плані оборони. Розроблення Плану оборони України, який би об'єднав всі програмні та планувальні документи 3 питань оборони забезпечить урахування всіх потенційних можливостей та їх системну реалізацію в інтересах збереження суверенітету та територіальної цілісності України;

визначення відповідального органу 3 планування оборони держави. Хоча ГШ формально $є$ головним військовим органом, для нього це буде дуже обтяжливо, через необхідність планування політичних, економічних та іншим державних заходів, а єдина система управління дасть змогу організувати ефективну взаємодію всіх складових сил оборони для стримування i відбиття гібридній агресії;

плани мають спиратися на реальні спроможності всіх складових сил оборони; в свою чергу спроможності потребують системного розвитку в рамках удосконаленої системи оборонного планування для здатності протидіяти гібридним загрозам;

підготовка населення, у тому числі організація руху опору на окупованих територіях;

підготовка території до оборони з урахуванням того, що деякі регіони можуть бути захоплені ворогом. створення відповідних баз, складів озброєння, мереж зв'язку тощо, корегування дислокації військових частин, підприємств ОПК та об'єктів критичної військової інфраструктури, уникнення випадків розташування зазначених об'єктів поблизу державного кордону;

підготовка всіх категорій військовослужбовців до дій в умовах гібридної війни. Командний склад усіх рівнів повинен мати практичні навички щодо організації взаємодії підрозділів Збройних Сил України 3 представниками МВС, Національної гвардії, СБУ тощо;

удосконалення підготовки військ, до ведення класичних форм збройного протистояння, а, також урахування особливостей гібридної війни, ведення бойових дій у населених пунктах, протидії провокаційним діям “цивільного населення" під час висування колон, розташування поблизу населених пунктів, розвантаження на залізничних станціях тощо), проведення заходів психологічної підготовки, виховання у військовослужбовців готовності використовувати зброю проти людей. Докорінна зміна системи підготовки офіцерів запасу на воєнних кафедрах у цивільних вищих навчальних закладах;

не лише протидія в інформаційному просторі протилежній стороні, а нормативно-правовий захист Збройних Сил України та інших військових формувань від негативного інформаційного впливу всередині держави, законодавче врегулювання та впровадження цензури, порядку й обмеження допуску журналістів в інформаційне поле, пов'язане із веденням бойових дій;

уточнення у територіальній обороні порядку охорони важливих державних, регіональних i місцевих об'єктів в умовах правового режиму воєнного стану, використання значного потенціалу державних i приватних охоронних структур, розроблення механізму їх залучення до охорони важливих державних об'єктів.

\section{Висновки й перспективи подальших досліджень}

Попри стирання традиційних уявлень про війну, викладена ще Клаузевіцем теза про те, що війна має постійну природу та змінний характер залишається актуальною (хоча не всі поділяють таку точку зору, вважаючи, що природа війни може змінитися під впливом нових технологій та форм війни, а війна може мати“іншу граматику”, яка грунтується на повстанських операціях). Під час аналізу гібридних воєн сучасності важливо це пам'ятати та розрізняти їх природу та характер. Ключовим завданням для пошуку відповіді на гібридний виклик стає оцінювання іiі воєнного аспекту, розуміння того, який елемент структури конфлікту залишиться незмінним, а який еволюціонуватиме.

Війна завжди буде актом насильства, який має на меті змусити суперника виконати вашу волю. Мотиви війни, сформульовані ще Фукідідом, так само будуть незмінні: страх, гордість й вигода. Характер та форма війни значною мірою залежать від технологій, економіки і рівня суспільного розвитку акторів. Наприклад, використання дронів та роботів у бойових діях вже $є$ звичним. Недержавні актори так само можуть бути стороною військового протистояння, більше того, їх значущість у воєнних конфліктах імовірно 
зросте. 3 розвитком комп'ютерних мереж кібервійни стають зброєю терористичних організацій та елементом гібридних воєн.

Досвід, набутий Україною, показав особливості військової парадигми сучасної гібридної війни, яка прискорила оборонні трансформації та структурні зрушення в секторі безпеки та оборони України спрямовані на мінімізацію загроз державному суверенітету, створення умов для відновлення

\section{Лimepamypa}

1. Hoffman F.G.Hybrid Warfare and Challenges / F.G. Hoffman // Joint Force Quarterly. - 2009. - 1st Quarter. - No 52. - P. 34-39. 2. Hoffman F.G. 'Hybrid Threats': Neither Omnipotent Nor Unbeatable [Електронний pe-сурс] / F.G. Hoffman. - Режим доступу: http://operationaladaptation.com/unify_uploads /files/Hoffman $\% 202010 \% 20$ Hybrid\%20Threats.pdf.

3. Клаузевиц К. О войне : в 2 т. / К. Клаузевиц. М. : ООО "Изд-во АСТ" ; СПб. : Terra Fantastica, 2002. 4. Указ Президента України "Про рішення Ради національної безпеки і оборони України від 6 травня 2015 року "Про Стратегію національної безпеки України” від 26 травня 2015 року № 287/2015 [Електронний ресурс]. - Режим доступу: www.president.gov.ua/documents/19521.html. 5. Указ Президента України "Про рішення Ради національної безпеки і оборони України від 2 вересня 2015 року “Про нову редакцію Воєнної доктрини України” від 24 вересня 2015 року № 555/2015 [Електронний ресурс]. Режим доступу: http://www.president.gov.ua/ documents/5552015-19443. 6. Указ Президента України територіальної цілісності у межах міжнародно визнаного державного кордону України, гарантування мирного майбутнього України як суверенної і незалежної, демократичної, соціальної, правової держави, а також забезпечення нової якості оборонного сектору, інтеграції України до Європейського Союзу та формування умов для вступу в НАТО.

"Про рішення Ради національної безпеки і оборони України від 4 березня 2016 року "Про Концепцію розвитку сектору безпеки і оборони України” від 14 березня 2016 року № 92/2016 [Електронний ресурс]. Режим доступу: www.president.gov.ua/documents/92201619832. 7. Указ Президента України "Про рішення Ради національної безпеки і оборони України від 20 травня 2016 року "Про Стратегічний оборонний бюлетень України” від 6 червня 2016 року № 240/2016 [Електронний ресурс]. - Режим доступу: www.president. gov.ua/documents/2402016-20137. 8. Світова гібридна війна: український фронт : монографія / За заг. ред. В. П. Горбуліна. - К.: НІСД, 2017. - 496 с. 9. Герасимов В. В. Ценность науки в предвидении// Военно-промышленный курьер. - 2013. - № 8 (476). - 27 февр. 10. Вікіпедія [Електронний ресурс]. - Режим доступу: https://uk.m.wikipedia.org>wiki>Дезінформація. 11. Свропейська правда [Електронний ресурс]. Режим доступу: www:eurointegration.com.ua

\section{АНАЛИЗ ВОЕННЫХ АСПЕКТОВ ГИБРИДНОЙ ВОЙНЫ: ИХ СОДЕРЖАНИЕ И УРОКИ ПРОТИВОДЕЙСТВИЯ \\ Ольга Федоровна Сальникова (д.н.ду, с.н.с.) \\ Виктор Сысоевич Корендович (к.т.н, доцент) \\ Павел Андреевич Минеев \\ Сергей Игоревич Антоненко}

\section{Национальный университет обороны Украины имени Ивана Черняховского, Киев, Украина}

Военные действия Российской Федерации с начала февраля 2014 года в Украине актуализировали парадигму вооруженного конфликта, когда сторона осуществляющая агрессию не афиширует себя. Модель, которая объединяет разные средства ведения военных действий с применением обычных видов вооружения нерегулярных войск и формирований, осуществление террористических актов и применение сепаратиских движений, известна в мире с начала ХХІ века как гибридная война. Именно изменение парадигмы современного вооруженного конфликта и гибридная агрессия РФ против Украины ускорили трансформацию и структурные изменения в секторе безопасности и обороны Украины. Создание и полноценное функционирование сектора безопасности и обороны, соответствующего условиям современного военного конфликта практически невозможны без научного анализа военных аспектов гибридной войны и объективного диагностирования проблем современной системы военной безопасности в условиях операции объединенных сил. В статье проанализированы военные аспекть гибридной войны и предложены приоритетные направления противодействия российской гибридной войне, а также будущим гибридным угрозам.

Ключевые слова: гибридная война; оборона государства; применение вооруженньх сил; система управления вооруженными силами; объединенное руководство силами оборонь.

\section{MILITARY ASPECTS HYBRID WARFARE'S COUNTERING: CONTENT AND LESSONS LEARNED}

Ol'ga F. Salníkova (Doctor Science du., s.n.s.)

Victor S. Korendovych (Ph.D., Associated professor) Serhii I. Antonenko

Pavlo A. Minieiev

National Defense University of Ukraine Ivan Chernyakhovsky, Kyiv, Ukraine 
Military actions of Russian Federation in the Eastern Ukraine since February 2014 has activated paradigm of armed conflict, when the aggressor does not display himself. Such a model, which integrates different means of conventional warfare, regular and irregular formations, terrorism and separatism, is well known since the beginning of 21 centuries as the hybrid war. Such a change of modern warfare paradigm and hybrid aggression of Russian Federation against Ukraine have built up impetus for acceleration transformation and structural changes in Security and Defence Sector (SDS) of Ukraine. Creation and effective functioning SDS of Ukraine which corresponds to modern armed conflict is impossible without scientific analysis of the military aspects hybrid war and comprehensive diagnostic the problems of functioning existing system of military security in the conditions of the Joint Forces operation. In the article has analysed the military aspects of hybrid war and proposed priority directions of Russian hybrid war countering as well as future hybrid threats.

Key words: hybrid warfare; defense of state; armed forces employment; defence forces, C2 of Armed Forces; joint management of defence forces

\section{References}

1.Hoffman F.G.Hybrid Warfare and Challenges / F.G. Hoffman // Joint Force Quarterly. - 2009. - 1st Quarter. No 52. - P. 34-39. 2. Hoffman F.G. 'Hybrid Threats': Neither Omnipotent Nor Unbeatable [Electronic resource] / F.G. Hoffman. - available at: http://operationaladaptation.com/unify uploads/files/Hoffm an $\% 202010 \% 20$ Hybrid\%20Threats.pdf. 3. Carl Philipp Gottlieb von Clausewitz. 'On War'. OOO publishing house АСТ Спб Terra Fantastica, 2002. 4. The Decree of the President of Ukraine "About the decision of The National Security and Defense Council of Ukraine on the $6^{\text {th }}$ of May 2015" About the National Security Strategy of Ukraine " of 26 May 2015 № 287/2015 [Pro ríshennya Radi natsional'noí bezpeki i oboroni Ukraini víd 6 travnya 2015 roku "Pro Strategíyu natsional'noi bezpeki Ukraini" víd 26 travnya 2015 roku № 287/2015], available at http://www.president.gov.ua/ documents/19521.html. 5. The Decree of the President of Ukraine "About the decision of The National Security and Defense Council of Ukraine on 2 September 2015" About the new edition of the Ukrainian Doctrine" on the $24^{\text {th }}$ of September 2015 № 555/2015 [Pro rishennya Radi natsional'noi bezpeki i oboroni Ukraini vid 2 veresnya 2015 roku "Pro novu redaktsíyu Voênnoi doktrini Ukraini" víd 24 veresnya 2015 roku № 555/2015], available at http://www.president.gov.ua/ documents/ 5552015-19443. 6. The Decree of the President of Ukraine " About the decision of The National Security and Defense Council of Ukraine on the 4th of February 2016" About the Concept of the security and defense sector of Ukraine development" of 14 of March 2016 № 92/2016 [Pro ríshennya Radi natsional'noi bezpeki i oboroni Ukraini víd 4 bereznya 2016 roku "Pro Kontseptsíyu rozvitku sektoru bezpeki i oboroni Ukraini" víd 14 bereznya 2016 roku № 92/2016]? , available at http://www.president.gov.ua /documents/ 922016-19832. 7. Decree of the President of Ukraine "About the decision The National Security and Defense Council of Ukraine on the 20th of May 2016 "About the Strategic Defense Bulletin of Ukraine" of 6 of October, 2016, № 240/2016 [Pro ríshennya Radi natsional'noi bezpeki i oboroni Ukraini víd 20 travnya 2016 roku "Pro Strategichniy oboronniy byuleten' Ukraini" vid 6 chervnya 2016 roku № 240/2016], available at http:/www.president.gov.ua/ documents / 2402016-20137. 8. World Hybrid War: Ukrainian Front: the monography [Svitova gíbridna víyna: ukrains'kiy front : monografiya] / under V. Gorbulin.edition - K .: NISS, 2017. - 496 c. - P. 34-39. 9. Valery Gerasimov, The Value of Science is in the Foresight. Military-Industrial Kurier. 2013. \# 8(476) . 10. Wikipedia [Electronic resource]. available at: https://uk.m.wikipedia.org>wiki> Дезінформація . 11. European Pravda [Електронний pecypc]. - available at: www:eurointegration.com.ua 